\title{
The State of Tourist Attractions in the Mun River Basin
}

\author{
Phan Champoosri ${ }^{1}$, Songkoon Chantachon ${ }^{1} \&$ Kosit Phaengsoi ${ }^{1}$ \\ ${ }^{1}$ The Faculty of Cultural Science, Mahasarakham University, Khamriang Sub-District, Kantarawichai District, \\ Maha Sarakham Province, Thailand \\ Correspondence: Phan Champoosri, The Faculty of Cultural Science, Mahasarakham University, Khamriang \\ Sub-District, Kantarawichai District, Maha Sarakham Province 44150, Thailand. E-mail: pchampoosri157 \\ @hotmail.com
}

$\begin{array}{lr}\text { Received: April 29, } 2014 & \text { Accepted: May 29, } 2014 \quad \text { Online Published: June 12, } 2014 \\ \text { doi:10.5539/ach.v6n2p176 } & \text { URL: http://dx.doi.org/10.5539/ach.v6n2p176 }\end{array}$

\begin{abstract}
This is a qualitative research that uses interviews and focus group discussions to assess the state of tourist attractions in five provinces along the Mun River in North-eastern Thailand. Fifteen tourist attractions are examined in seven categories: transportation, food, accommodation, souvenirs, information services, activities and marketing. Both cultural and natural attractions have similar problems. The attractions have poor access roads, weak identities, a lack of information and inadequate services. A set of suggestions are made to combat the problems that can be summarised as five general solutions to combat obstacles to cultural tourism and ecotourism in the area. Firstly, management must place greater emphasis on cultural heritage. Secondly, local institutions must provide more sponsorship. Thirdly, community participation must be increased. Fourthly, attractions must be systematically regulated. Finally, information and education must be prioritised.
\end{abstract}

Keywords: tourist attractions, Mun River Basin, cultural tourism, ecotourism, Thailand

\section{Introduction}

Thailand has an ancient and varied culture that includes unique language, literature, art, dance, music, architecture, artefacts and customs. Thai culture is a large part of everyday life (Ministry of Culture, 2002). Consequently, conservation of this culture improves the quality of local life and adds value to the economy by boosting tourism (Chuchat et al., 2001). For this reason, cultural conservation on a local and regional scale is a way to propel national growth and must be considered of huge importance.

The Mun River is a large tributary of the Mekong River that flows through five provinces in North-eastern Thailand: Nakhon Ratchasima, Buriram, Surin, Sisaket and Ubon Ratchatani. The Mun River is an important irrigation source for the famous rice growing region, Tung Kula Rong Hai and excavations in the area have found evidence that the river was important to the Dvaravati, Khmer and Ayutthaya Civilizations (Boonsiri, 2008). Moreover, in a fifteen kilometre radius from the main trunk of the river, there are traces of prehistoric communities, including skeletons, earthenware pots, metals and cave paintings (Chantachon, 2006b). These findings are at excavation sites such as Ban Prasat in Nakhon Ratchasima and Pa Taem in Ubon Ratchatani. They show that the Mun River has been a vital natural resource to humans for over 3,500 years.

Having been the lifeblood of local communities over the course of history, the Mun River is proving a valuable asset to national tourism (Peleggi, 1996). Different historical civilizations made their own fine and elaborate architectural imprints on the landscape, which are now hotspots of cultural tourism (Jaroomanee, 2001). Prasat Hin Pimai in Nakhon Ratchasima, Prasat Sra Kamphaeng Yai and Sra Kamphaeng Noi in Sisaket, Prasat Nangbuatum in Surin and Wat Tung Sri Mueang in Ubon Ratchatani are all examples of historical architectural sites that have been adapted to accommodate cultural tourism in the Mun River Basin. In addition, the Mun River is a source of growing ecotourism in the North-eastern region of Thailand (Boonsiri, 2008). Given the appeal of the region, the research team conducted this investigation to assess the state of cultural and natural tourist attractions in the Mun River Basin and suggest areas for improvement.

\section{Literature Review}

Defining tourism is a tricky task. There are now dozens of categories of tourism from domestic to international, adventure to heritage (Pender \& Sharpley, 2005). This investigation covers cultural tourist attractions and natural tourist attractions, so by extension cultural heritage tourism and ecotourism (Goeldner \& Brent Ritchie, 2009; 
White, 1996). It is possible, as Songkoon Chantachon (2006b) has done, to bracket natural attractions under the heading of cultural attractions. Indeed, using the Heritage Canada Foundation definition of a cultural landscape as the relationship between people, nature and history, then it is highly accurate (Heritage Canada Foundation, 2001). However, this study is aimed at identifying problems with the attractions so it is more appropriate to treat the attractions based on consumer definitions: natural tourist attractions are places of 'authentic' nature and cultural tourist attractions are places of 'authentic' culture (NWHO, 1999).

\subsection{The Mutual Relationship between Tourism and Community Development}

Tourism causes community lifestyle to change (Meeboon, 2000). It has a positive influence by generating income, encouraging cultural adaptation and strengthening relationships (Jamroonsiri, 2003; Prachumdaeng, 1990; Preissing, 2006; Santisombat, 2001). Additionally, tourism helps a community organize its culture and daily life (Singkra, 2001). Although tourism causes economic structures to evolve and expand, it also displaces traditional occupation-based social concepts (Prajong, 2003). In a study of tourism along the Amazon River, Wallace and Pierce (1996) found that traditional jobs in the local community, such as fishing, were being abandoned in favour of more lucrative careers in tourism. Tourism has similarly been identified as a primary cause for the disappearance of traditional lifestyle in North-eastern Thailand (Suwanadee, 1995).

Unique identifying characteristics in communities cause the conservation of cultural and natural heritage (Wiengkaew, 2009). As Stem (2003) explains, although national laws and the level of community education are also factors, high potential for future tourism income drives cultural conservation. Not only this, but a strong and distinctive local identity attracts tourists to a place (Saenkam, 2002). Tourism is at its most appealing when traditional knowledge is a focal point of tourism management (Escobar, 1998; Lu, 2006). Tourists are interested in both tangible and intangible cultural heritage (Forristal, 2009). Natural beauty is another factor in attracting tourists (Pimonsri, 1993).

In a case-study of community development in rural Cambodia, Carolyn Cork noted the importance of tourism for the development of local infrastructure (Cork, 1996). Five suggestions were made by Cork to successfully use tourism as a means of community development: 1) the community must participate in tourism initiatives and take pride in their heritage; 2) conservation information must be provided for visiting tourists; 3 ) social and environmental aspects of tourism must be planned and efficiently managed; 4) the community must be made aware of the tangible benefits of tourism; 5) government institutions must cooperate in future ecotourism research projects to help continuously develop the local community. The higher number of interested parties in tourism development, the greater the results (Sprecher \& Jamieson, 2000).

Patcharee Boonsiri (2008) found the poor quality of Mun River water to have a negative effect on tourism in the area. Wildlife in and around the Mun River has decreased in recent times (Prongjaroen, 2004). Complimenting these findings, there have been numerous case studies to assess the make-up of visitors to cultural attractions in North-eastern Thailand and all of them highlight individual problems with tourism management that have an adverse effect on the local communities (Paopongchuwong, 2004; Seehaban, 2002; Sermwilasakun, 2004). In light of these investigations it is especially important to conduct an assessment of the state of tourism in the Mun River Basin, not only to improve tourism potential in the area but also to benefit the local communities.

\section{Methodology}

This is a qualitative investigation comprising documentary study and field research from July 2012 to November 2013. The aim of this investigation is to identify problems with tourist attraction management in the Mun River Basin and make suggestions for tourism development. The research area covers five provinces in North-eastern Thailand - Nakhon Ratchasima, Buriram, Surin, Sisaket and Ubon Ratchatani - and includes fifteen tourist attractions (Table 1). There were five criteria for selecting tourist attractions for this investigation: they were in one of the five aforementioned provinces; they were natural or cultural attractions; they were in the development plans of the provincial tourism office; they were already considered of important local significance; they had management problems. The research population was composed of people working at, visiting and living near fifteen tourist attractions in the Mun River Basin. The research sample was identified by purposive sampling and totalled 210 individuals, divided into three groups. The first group (key informants) was composed of one representative from the provincial tourism and sport office of each province, the provincial governor of each province, one representative from the culture office of each province, 15 district culture officers, managers from each tourist attraction, 15 sub-district administration chiefs, 15 local community representatives and 15 academics. The second group (casual informants) was composed of 15 tour guides, 15 souvenir makers, 15 local merchants, 15 community leaders, 15 supplementary occupation group representatives and 15 representatives 
from local accommodation businesses. The third group (general informants) was composed of 15 local residents and fifteen attraction visitors.

Table 1. A list of tourist attractions covered by the investigation

\begin{tabular}{|c|c|c|c|c|}
\hline \multicolumn{3}{|c|}{ Natural tourist attractions } & \multicolumn{2}{|c|}{ Cultural tourist attractions } \\
\hline \multirow{3}{*}{$\begin{array}{l}1 . \\
\text { Buriram. } \\
2 .\end{array}$} & \multirow{2}{*}{\multicolumn{2}{|c|}{$\begin{array}{llll}\text { Khao } & \text { Kradong } & \text { Forest } & \text { Park, }\end{array}$}} & \multirow{2}{*}{$\begin{array}{l}1 . \\
2 .\end{array}$} & \multirow{2}{*}{$\begin{array}{l}\text { Wat Kao Jan Ngam, Nakhon Ratchasima. } \\
\text { The scripture tower of Wat Na Phra That, Nakhon }\end{array}$} \\
\hline & & & & \\
\hline & \multicolumn{2}{|c|}{ Saneng Dam, Surin. } & \multicolumn{2}{|c|}{ Ratchasima. } \\
\hline 3. & \multicolumn{2}{|c|}{ Samrongkiat Waterfall, Sisaket. } & 3. & Ban Kruat Stone Quarry, Buriram. \\
\hline 4. & Wang & Tao Waterfall, Nakhon & 4. & Wat Buraparam, Surin. \\
\hline \multicolumn{3}{|c|}{ Ratchasima. } & 5. & Ban Tha Sawang Weaving Village, Surin \\
\hline \multirow[t]{6}{*}{5.} & \multirow{6}{*}{\multicolumn{2}{|c|}{ Phu Ma Nai Cave, Ubon Ratchatani. }} & 6. & Prasat Wat Kamphaeng Yai, Sisaket. \\
\hline & & & 7. & Wat Pa Maha Chedi, Sisaket. \\
\hline & & & 8. & The scripture tower of Wat Tung Sri Mueang, Ubon \\
\hline & & & \multicolumn{2}{|c|}{ Ratchatani. } \\
\hline & & & 9. & Wat Kao Phra Angkarn, Buriram. \\
\hline & & & 10 & Wat Sawang Arom, Ubon Ratchatani. \\
\hline
\end{tabular}

The research tools used for field data collection during this investigation were basic survey, formal interview, informal interview, participant observation, non-participant observation and focus group discussion. An initial basic survey was used to gather general information about the local lifestyle, society, cultural practices, tourist attractions and research context. Formal interviews were then conducted with the sample groups to identify problems with tourism management in the fifteen locations covered by the research. Further informal interviews were held with key informants to collect any data missed by the formal interviews. This second round of interviews was not limited by fixed questions. The research team observed the attractions and local communities using two methods of observation: participant and non-participant (Chantachon, 2006). The final stage of research was focus group discussions. Five discussions involving five to ten individuals were held to make suggestions for solving the problems found by the interviews and observations.

During field research, data was recorded in a notebook and photographs were taken by camera. The collected data was analysed daily and similar data was organized into one of two groups: natural tourist attractions and cultural tourist attractions. Sub-categories were created in each group for the purposes of typological analysis and analytic induction. The seven sub-categories chosen for analysis were based on those used in similar domestic case studies and adapted for specific application to this study (Boonprab, 2005; Hiranyahat, 2001; Sarnson, 1990). The categories were transportation, food, accommodation, souvenirs, tourist information services, activities and marketing. All data was validated using the four-stage triangulation process of Supang Chantavanit (2002). The data is here presented as a descriptive analysis.

\section{Results}

\subsection{The State of Natural Tourist Attraction Management in the Mun River Basin}

Khao Kradong Forest Park, Saneng Dam and Samrongkiat Waterfall each have more than two main access routes. Private cars and public transportation visit the attractions every day and there are clearly defined parking and turning areas. The locations with obvious transportation weaknesses are Wang Tao Waterfall and Phu Ma Nai Cave. The access roads to both of these sites are narrow, covered with loose chippings and impassable at certain times of the year. Parking and turning vehicles is also difficult: "there is no system for parking vehicles around the attractions." (J. Pitmak, personal communication, 2013)

Food is available at Khao Kradong Forest Park, Saneng Dam and Phu Ma Nai Cave. "Food is provided by the locals based on their own home-cooking. This means there are no regulations, hygiene standards and the food lacks quality." (D. Attit, personal communication, 2013) There are no food outlets at either of the waterfalls. There are home-stays and hotels ranging from 100 to 500 baht per night in most of the local communities but there is nothing close to the natural attractions: "There are no accommodation options for tourists" (D. Attit, personal communication, 2013). There are stalls and stores at Khao Kradong Forest Park and Phu Ma Nai Cave selling locally produced souvenirs under the government One Tambon, One Product (OTOP) scheme. There are no stalls selling local wares at Saneng Dam and the two waterfalls. 'They need someone in charge to organise training so that locals can develop souvenirs according to consumer demand rather than make the same old stuff." 
(D Raksa, personal communication, 2013)

It is possible to contact representatives from Khao Kradong Forest Park, Saneng Dam, Samrongkiat Waterfall and Phu Ma Nai Cave at any time. All of the aforementioned attractions have an internet presence and information for each is provided by the tourism office and the local community office. Signs are also posted on site to provide tourists with background and historical information about conservation projects and success. There is no regularly updated online information for Wang Tao Waterfall, there are no information signs and visitors are unable to determine the impact of human activity at the site and the effect of conservation. At Khao Kradong Forest Park there are hiking trails up Kradong Mountain. At each of the sites there are a varied number of activities, including rafting, bird and butterfly watching, fishing and camping. However, organised tourist activities are only held on important national days and there are no events specifically related to the locations. There are human resources teams at Khao Kradong Forest Park, Saneng Dam, Samrongkiat Waterfall and Phu Ma Nai Cave. They are responsible for production of promotional literature, marketing campaigns and local radio advertisements. There are weak public relations at Wang Tao Waterfall due to a lack of budget and personnel. There are consequently no advertisements and no signs around the attraction.

\subsection{The State of Cultural Tourist Attraction Management in the Mun River Basin}

Wat Kao Jan Ngam, the scripture tower of Wat Na Phra That, Ban Kruat Stone Quarry, Wat Buraparam, Ban Tha Sawang Weaving Village, Prasat Wat Kamphaeng Yai, Wat Pa Maha Chedi and the scripture tower of Wat Tung Sri Mueang are all accessible by more than two routes. There is regular public transport at each of the aforementioned cultural attractions and there is ample parking and turning space. The biggest transportation problems are at Wat Kao Phra Angkarn and Wat Sawang Arom because the access roads are steep and narrow. At Wat Kao Phra Angkarn, there are many heavy goods vehicles and it is difficult to turn vehicles.

The food variety on offer at Wat Buraparam, Prasat Wat Kamphaeng Yai, Wat Pa Maha Chedi and the scripture tower of Wat Tung Sri Mueang is good because the attractions are located in the city centre. For other attractions, "tourists prefer to buy food en route to consume at their destinations." (K. Chomngam, personal communication, 2013) There are home-stays and hotels ranging from 100 to 500 baht per night in most of the local communities. However, there are no accommodation options near Wat Kao Jan Ngam, Ban Kruat Stone Quarry or Wat Sawang Arom, so "tourists must stay in the nearest town." (S. Chaipit, personal communication, 2013) Attractions with the strongest state of locally produced souvenirs are Wat Buraparam, Ban Tha Sawang Weaving Village, Prasat Wat Kamphaeng Yai and the scripture tower of Wat Tung Sri Mueang. However, there is a lack of souvenir variety at all locations and no souvenir stalls at Wat Kao Jan Ngam.

It is possible to contact representatives from Wat Buraparam, Ban Tha Sawang Weaving Village, Prasat Wat Kamphaeng Yai and the scripture tower of Wat Tung Sri Mueang at any time. All of the aforementioned attractions have an internet presence and information is provided on-site in the form of leaflets. The biggest general problem is insufficient signposting. "If tourists want to know anything about the sites, they need to do research beforehand because on-site information is inadequate." (W. Makmayom, personal communication, 2013) Wat Kao Jan Ngam is the attraction with the lowest level of public information and weakest online presence. At all locations, staff are inadequately trained and possess limited knowledge of the local cultural heritage. Performances are held at Prasat Wat Kamphaeng Yai. The attraction with fewest tourist activities is Wat Kao Jan Ngam, which only holds tourist activities on important national days and does not organize any events specifically related to the location. There are human resources teams at Wat Buraparam and Prasat Wat Kamphaeng Yai. They are responsible for production of promotional literature, marketing campaigns and local radio advertisements. There are weak public relations at the scripture tower of Wat Na Phra That and Ban Kruat Stone Quarry due to a lack of budget and personnel. There are consequently no advertisements and no signs around the attraction.

Following observation and interviews, the respondents outlined their suggestions for development of tourist attractions in the Mun River Basin. These suggestions were gathered during focus group discussions and are summarized in Table 2. 
Table 2. Suggested solutions for management problems at the fifteen attractions

\begin{tabular}{|c|c|c|}
\hline Category & Natural Tourist Attractions & Cultural Tourist Attractions \\
\hline Transportation & $\begin{array}{l}\text { - Uneven and collapsing roads } \\
\text { must be repaired. } \\
\text { - There must be cleaning and } \\
\text { maintenance campaigns on designated } \\
\text { days to make the entrances to tourist } \\
\text { attractions more impressive and appealing. } \\
\text { - There should be an increase of } \\
\text { public transport frequency. } \\
\text { - Traffic inside the tourist } \\
\text { attractions must be controlled. }\end{array}$ & $\begin{array}{l}\text { - Industrial and heavy-goods } \\
\text { vehicles should not be allowed to enter the } \\
\text { tourist attractions in the high season. } \\
\text { - Uneven and collapsing roads must } \\
\text { be repaired. }\end{array}$ \\
\hline Food & $\begin{array}{l}\text { - Local food should be sold at } \\
\text { stalls or restaurants in or around the } \\
\text { attractions. } \\
\text { - Food stalls must be maintained } \\
\text { to standardized food safety regulations. }\end{array}$ & $\begin{array}{l}\text { - Local food should be sold at stalls } \\
\text { or restaurants in or around the attractions to } \\
\text { promote the culture of the local community. } \\
\text { - A convenience store should be } \\
\text { established. }\end{array}$ \\
\hline Accommodation & $\begin{array}{l}\text { Regulated home-stay } \\
\text { accommodation must be provided in the } \\
\text { community and resort or hotel } \\
\text { accommodation available outside. }\end{array}$ & $\begin{array}{l}\text { Regulated home-stay } \\
\text { accommodation must be provided in the } \\
\text { community and resort or hotel } \\
\text { accommodation available outside. }\end{array}$ \\
\hline Souvenirs & $\begin{array}{l}\text { - The local community must sell } \\
\text { souvenirs promoting the area and society } \\
\text { surrounding the attractions. }\end{array}$ & $\begin{array}{l}\text { - The local community must sell } \\
\text { souvenirs promoting the area and society } \\
\text { surrounding the attractions. }\end{array}$ \\
\hline $\begin{array}{l}\text { Tourist } \\
\text { information } \\
\text { services }\end{array}$ & $\begin{array}{l}\text { - A public announcement facility } \\
\text { must be created in the local communities. } \\
\text { - Information must be made } \\
\text { available at all times. } \\
\text { - Websites must be created and } \\
\text { regularly updated. } \\
\text { - There must be guide services } \\
\text { provided at each attraction. }\end{array}$ & $\begin{array}{l}\text { There must be training to educate } \\
\text { staff in the history of the attraction and } \\
\text { surrounding community. } \\
\text { - Seminars should be organized to } \\
\text { make the local community realize the } \\
\text { importance of the tourist attractions. } \\
\text { - Signs and maps should be created } \\
\text { for the tourist attractions. }\end{array}$ \\
\hline Activities & $\begin{array}{l}\text { - Activities must be organized } \\
\text { with participation from the local } \\
\text { communities, temples and schools to } \\
\text { strengthen relationships in the area. } \\
\text { - Activities must be aimed at } \\
\text { conserving traditional culture and } \\
\text { resources. }\end{array}$ & $\begin{array}{l}\text { A committee should be established } \\
\text { in the local community to liaise with the } \\
\text { tourist attractions and organize cultural } \\
\text { activities. }\end{array}$ \\
\hline Marketing & $\begin{array}{l}\text { - Advertising on the local } \\
\text { loudspeaker system } \\
\text { supplemented by leaflets. }\end{array}$ & $\begin{array}{l}\text { A local official must be made } \\
\text { responsible for marketing in the community } \\
\text { and organization of promotional gatherings to } \\
\text { generate community interest and } \\
\text { participation. }\end{array}$ \\
\hline
\end{tabular}

\section{Discussion}

A common problem at both natural and cultural tourist attractions in the Mun River Basin is the poor state of the access roads. Respondents at all sites made maintenance of access roads and traffic regulation high priority. In 
order to perform the required maintenance work, "the local government needs to allocate a higher proportion of the annual budget. With increased funding and a more focused plan, the roads would no longer be a problem." (S Buadaeng, personal communication, 2013) The inadequate budget has been an obstacle for over a decade. In 2002, Kitirat Seehaban (2002) conducted an evaluation of cultural tourist attractions in Ubon Ratchatani and found traffic to be a problem at all sites. Seehaban concluded that although the attractions are the cause of increased traffic problems, they also provide the community with increased income that can be put towards the solution.

Prapassorn Paopongchuwong (2004) found that food served in the natural and cultural tourist attractions of Ubon Ratchatani lacked quality because it was provided by local families based on their own food preferences. During this research, respondents indicated that locally sourced and produced food was preferable to national or global cuisine. The reasons for this were low production cost and promotion of local identity. In light of Paopongchuwong's findings and while local food is ideal, it must be remembered that food variety and restaurant atmosphere are important to the visiting tourists.

Accommodation is vital to the success of tourism in the Mun River Basin because it gives visitors a platform from which to access each of the natural and cultural attractions. A study of Phimai Historical Park (Sermwilasakun, 2004) found that sincerity, honesty, comfort and safety were the main concerns of visiting tourists regarding accommodation. Further study must be conducted in the Mun River Basin to determine the preferences of visitor types and outline specifications for tourist accommodation. Once these preferences have been identified, steps can be taken to standardize accommodation according to tourist demand (Wight, 1997). "Really, the home-stays should be regulated to bring their services in line with international standards."(S. Songkratok, personal communication, 2013)

Locally produced souvenirs are more valuable to tourists than general mass-produced commercial merchandise (Paopongchuwong, 2004). For this reason, the local community must sell souvenirs promoting the area and society surrounding the attractions. "The government already sponsors the sale of locally produced souvenirs but there must be greater organization within the community and a proactive effort to educate locals in product development." (S. Yonkratok, personal communication, 2013)

Community participation and active provision of updated information is particularly important in the development of tourist attractions in the Mun River Basin because they create a relationship between the attractions and society. "Many changes need to be made to local information services but they can't be made without funding." (S. Buadaeng, personal communication, 2013). Successful cultural tourism projects in Thailand, all have an element of organized local participation and government sponsorship (Na Ranong, 2002). It is also important for the head of the community, or a representative, to take a personal interest in the relationship between the community and its attractions (Watanasukchai, 2002).

Tourist activities are forms of cultural ecology that enable visitors to relate to the attraction (Steward, 1972). The activities must be modern representations of traditional culture so that tourists may understand the surrounding environment. The most successful tourist attractions are those whose environment facilitates adaptation of activities to meet modern demand (Hiranyahat, 2001). In this respect, the surrounding environment must include the surrounding population. "The local community needs to be more involved in attraction management, particularly the organization of everyday activities" (C. Yotkratok, personal communication, 2013). Additionally, there must be greater involvement from local institutions, particularly established government agencies, schools and temples. "The local council and the schools need to support marketing because they are the institutions we trust." (W. Putjakoh, personal communication, 2013).

\section{Conclusion}

Tourism is important to the local economy of the Mun River Basin but more efficient management could give attractions a greater appeal. While there are problems with cultural and natural attractions in seven categories, there are five common areas that must be addressed, which are very similar to those suggested by Carolyn Cork (1996). Firstly, tourism officials and management teams at the attractions must pay greater attention to the local community and local heritage. By focusing on traditional food and souvenirs, a stronger identity and relationship with the area can be forged to attract visitors. Secondly, local, regional and national institutions must take a greater interest and make a greater financial contribution to the management of the sites and their surroundings, especially transport links. Thirdly, local residents must be educated in the advantages of a thriving tourist attraction with extensive community participation. With increased community participation, the attractions will also benefit from more accurate and unique traditional knowledge. Fourthly, stricter regulations must be in place to improve the tourist experience. These include food hygiene, souvenir quality, staff development and activity 
management. Finally, information and learning must be made a high priority of all attractions. Educational material must be developed and provided for tourists but also to train staff and encourage participation from the local communities. These changes will reinforce the potential of tourism in the Mun River Basin with a distinctive local character and ensure that cultural tourism and ecotourism continue to flourish in the region.

\section{References}

Boonprab, W. (2005). The development of the tourism industry on Koh Samui, Koh Samui District, Surat Thani Province [in Thai]. Unpublished $\mathrm{PhD}$ thesis, Thaksin University, Thailand.

Boonsiri, P. (2008). Quality of water in the Mun River at Pimai District, Nakhon Ratchasima Province and Ubon Ratchatani Province for waterway tourism [in Thai]. KKU Research Journal, 13(1), 153-162.

Chantachon, S. (2006a). Cultural qualitative research [in Thai]. Mahasarakham: Research Institute of Northeastern Art and Culture.

Chantachon, S. (2006b). The study and development of cultural tourism in Mahasarakham Province [in Thai]. Mahasarakham: Research Institute of Northeastern Art and Culture.

Chantavanit, S. (2002). Qualitative research method [in Thai]. Bangkok: Chulalongkorn University Press.

Chuchat, C. et al. (2001). A model of ecotourism in the Mae Wang River Basin [in Thai]. Bangkok: Thailand Research Fund.

Cork, C. (1996). Community-managed ecotourism: A feasibility survey in Phnom Baset, Cambodia. Calgary: University of Calgary.

Escobar, A. (1998). Whose knowledge, whose nature? Biodiversity, conservation, and the political ecology of social movements. Journal of Political Ecology, 5, 53-82.

Forristal, L. J. (2009). Perceived attractiveness and dimensionality of culture-based tourism opportunities for Prophetstown. Unpublished $\mathrm{PhD}$ thesis, Purdue University, West Lafayette, IN, USA.

Goeldner, C., \& Brent Ritchie, J. (2009). Tourism: Principles, practices, philosophies. Hoboken, NJ: Wiley

Heritage Canada Foundation. (2001). Exploring the connection between built and cultural heritage. Research report. Ontario: Heritage Canada Foundation.

Hiranyahat, R. (2001). A method for developing the potential of cultural tourism villages: A case study of Ban Non Kao, Ta Muang District, Kanchanaburi Province [in Thai]. Chiang Mai: Chiang Mai University.

Jamroonsiri, A. (2003). Tourism and changes to the economy, society and culture: A case study of Nongbua Sub-district, Phuruea District, Loei Province [in Thai]. Loei: Loei Rajabhat Institute.

Jaroomanee, N. (2001). Tourism and management of the tourism industry [in Thai]. Bangkok: Odeon Store.

Lu, S. -Y., (2006). Control power, tourism development and conservation: Planning an island with a traditional culture. Unpublished PhD thesis, Harvard University, Boston, MA, USA.

Meeboon, S. (2000). Lifestyle changes of city communities with respect to society, economy, politics and education [in Thai]. Unpublished PhD thesis, Chiang Mai University, Thailand.

Ministry of Culture. (2002). Ethnic groups with a cultural heritage that shows their identity [in Thai]. Bangkok: Ministry of Culture.

Na Ranong, S. (2002). Local community management of tourism: A case study of Sri Wong Community, Kamlone Sub-district, Lansapa District, Nakhon Si Tammarat Province [in Thai]. Bangkok: Thammasat University

NWHO (1999). Sustainable tourism and cultural heritage: A review of development assistance and its potential to promote sustainability. Retrieved from March 26, 2014, http://www.nwhf.no/files/File/culture fulltext.pdf

Paopongchuwong, P. (2004). Behavior and impressions of tourists visiting Ubon Ratchatani Province [in Thai]. Mahasarakham: Mahasarakham University.

Peleggi, M. (1996). National heritage and global tourism in Thailand. Annals of Tourism Research, 23(2), 432-448. http://dx.doi.org/10.1016/0160-7383(95)00071-2

Pender, L., \& Sharpley, R. (2005). The management of tourism. London: Sage.

Pimonsri, P. (1993). The effect of rambling tourists: A case study of Mae Jaem District, Chiang Mai Province [in Thai]. Chiang Mai: Chiang Mai University. 
Prachumdaeng, K. (1990). Economic and social influence of tourism development for the people of Ku Deau, Jeramae Sub-district, Mueang District, Ubon Ratchatani Province [in Thai]. Unpublished PhD thesis, Sri Nakharinwirot University, Thailand.

Prajong, K. (2003). The effect of tourism on the community: A case study of Ban Sri Tan community, Sri Tan Sub-district, Phukradeung District, Loei Province [in Thai]. Unpublished PhD thesis, Loei Rajabhat University, Thailand.

Preissing, J. (2006). Community economic development strategic planning for rural communities: A case study of successful programs. Ann Arbor, MI: Proquest

Prongjaroen, M. (2004). Tourism potential of wildlife locations along the Mun River [in Thai]. Unpublished PhD thesis, Khon Kaen University, Thailand.

Saenkam, W. (2002). Development of cultural tourism at Ban Piang Luang, Wieng Haeng District, Chiang Mai Province [in Thai]. Unpublished $\mathrm{PhD}$ thesis, Chiang Mai University, Thailand.

Santisombat, Y. (2001). Ecotourism, cultural variety and resource management [in Thai]. Chiang Mai: Nopburi Printing.

Sarnson, N. (1990). The effect of the tourism industry on socio-economic status at Damnoen-Saduak Floating Market, Damnoen-Saduak District, Ratchaburi Province [in Thai]. Unpublished PhD thesis, Chulalongkorn University, Thailand.

Seehaban, K. (2002). Evaluation of the conditions of cultural tourist attractions in Ubon Ratchatani Province and a method for development [in Thai]. Unpublished $\mathrm{PhD}$ thesis, Ubon Ratchatani Rajabhat University, Thailand.

Sermwilasakun, A. (2004). A method for developing tourism at Phimai Historical Park, Phimai District [in Thai]. Mahasarakham: Mahasarakham University.

Singkra, P. (2001). Community potential for home-stay ecotourism management at Ban Huai Hee, Boo Ling Sub-district, Mueang District, Mae Hong Son Province [in Thai]. Unpublished PhD thesis, Chiang Mai University, Thailand.

Sprecher, D., \& Jamieson, D. (2000). A Manual for Monitoring Community Tourism Development. Pathum Thani: Canadian Universities Consortium Urban Environmental Management Project, Asian Institute of Technology.

Stem, C., Lassoie, J., Lee, D., \& Deshler, D. (2003). How 'eco' is ecotourism? A comparative case study of ecotourism in Costa Rica. Journal of Sustainable Tourism, 11(4), 322-347. http://dx.doi.org/10.1080 /09669580308667210

Steward, J. H. (1972). Theory of culture change: The methodology of multilinear evolution. Champaign, IL: University of Illinois Press.

Suwanadee, A. (1995). Economic and social influence of tourism at Kaeng Kut Koo, Ban Noi, Chiang Kan Sub-district, Chiang Kan District, Loei Province [in Thai]. Unpublished PhD thesis, Mahasarakham University, Thailand.

Wallace, G. N., \& S. M. Pierce. (1996). An evaluation of ecotourism in Amazonas, Brazil. Annals of Tourism Research, 23(4), 843-873. http://dx.doi.org/10.1016/0160-7383(96)00009-6

Watanasukchai, S. (2002). The relationship between locals and visitors: A case study of the conserved Thai-style tourism village at Ban Pla Pong Pang, Amphawa District, Samut Songkram Province [in Thai]. Unpublished $\mathrm{PhD}$ thesis, Thammasat University, Thailand.

White, P. (1996). North American ecotourists: Market profile and trip characteristics. Journal of Travel Research, 34(4), 2-10. http://dx.doi.org/10.1177/004728759603400401

Wiengkaew, C. (2009). The perspectives and dynamics of cultural tourism at Ban Pa-aow, Mueang District, Ubon Ratchatani Province [in Thai]. Unpublished PhD thesis, Mahasarakham University, Thailand.

\section{Copyrights}

Copyright for this article is retained by the author(s), with first publication rights granted to the journal.

This is an open-access article distributed under the terms and conditions of the Creative Commons Attribution license (http://creativecommons.org/licenses/by/3.0/). 